\title{
Clear Cell Sarcoma Kidney: Pitfalls and Management
}

\author{
Parveen Kumar, Priti Kumari and Yogesh Kumar Sarin* \\ Department of Pediatric Surgery, Maulana Azad Medical College, India \\ Received: December 15, 2017; Published: January 18, 2018
}

*Corresponding author: Yogesh Kumar Sarin, Director Professor \& Head, Department of Pediatric Surgery, Maulana Azad Medical College, New Delhi, India, Email: yksarin@hotmail.com

\begin{abstract}
Clear cell sarcoma of kidney (CCSK) is a highly malignant renal tumor of childhood. Here reported are two cases of CCSK, whose management went through dilemmas of histopathology and multimodal treatment, finally settling in regular long term period of follow up. The pitfalls in pathological examination of CCSK and role of radiotherapy in its management have been discussed.

Keywords: Clear cell sarcoma of kidney CCSK; Wilms' tumor
\end{abstract}

\section{Introduction}

Clear cell sarcoma of kidney (CCSK), previously known as bone metastasizing renal tumor of childhood is a distinct primary kidney tumor in children [1]. It is highly aggressive and constitutes approximately $4-6 \%$ of all pediatric renal tumors [2]. Mean age at diagnosis in the NWTS group was 3 years with a range of 2 months to 14 years [3]. It is highly malignant with higher relapse rates and wider distribution of metastasis than Wilms' tumor (WT) to bone, lymph nodes, lung, liver, brain [46]. Usually they are unilateral \& unicentric. Here are reported 2 cases of CCSK managed at our center.

\section{Case 1}

A 3.5-years-old boy presented with a left abdominal swelling, noticed 10 days back. On examination, the patient had pallor and systloic blood pressure was 90/50 mm $\mathrm{Hg}$. Abdominal examination revealed a firm, non-tender mass in the left hypochondrium and lumbar regions. Routine blood investigations, urine routine and the chest radiograph were within normal limits. Ultrasonography (USG) and contrast enhanced computerized tomography (CECT) scan showed 10x12 $\mathrm{cm}$ heterogeneous mass arising from the left kidney with foci of calcification noted in its periphery (Figure 1). Trucut biopsy showed round blue cell tumor with possibility of neuroblastoma, but immune histochemistry (IHC) was not contributory (Figure 2). The 24 hour urinary vanillylmandelic acid, homo-vanellic acid and bone marrow biopsy were normal. In view of the radiological features favoring WT, preoperative chemotherapy of 2 drugs (actinomycin D and vincristine in brackets) was given for 4 weeks. Post-chemotherapy CECT suggested no response. Left nephroureterectomy with lymph node (LN) berry picking was done. Postoperative histopathological examination (HPE) showed the tumor arising from the upper pole of left kidney, with features of classic type of clear cell sarcoma of kidney with focal myxoid and trabecular areas and no necrosis or infiltration of capsule or perinephric fat.

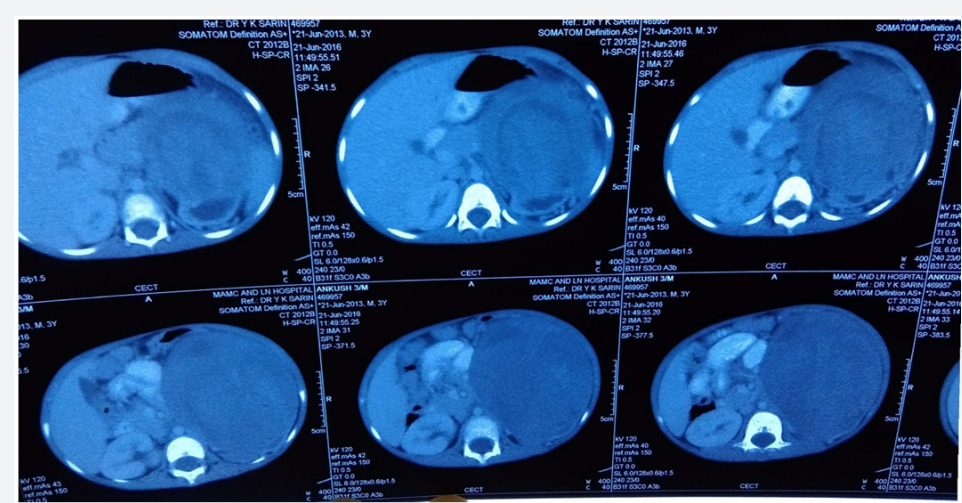

Figure 1: CECT image of case 1. 


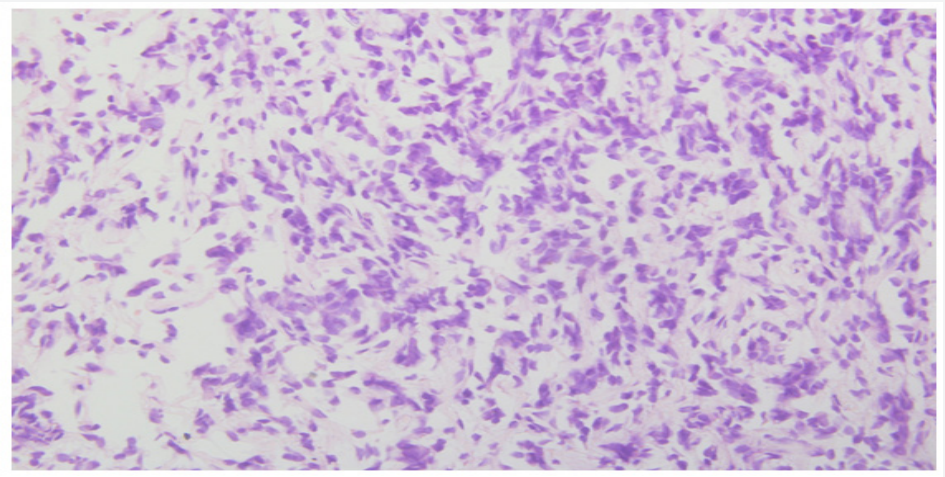

Figure 2: Histology picture of case 1.

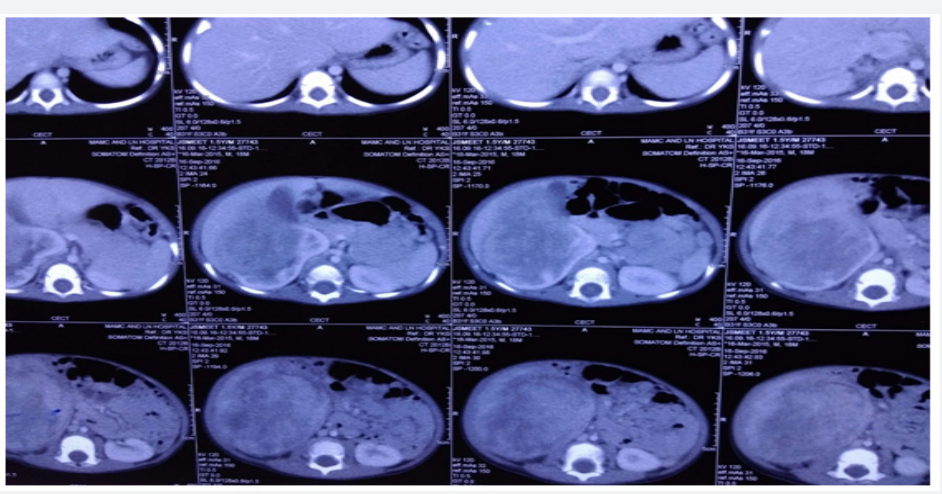

Figure 3: CECT image of case 2.

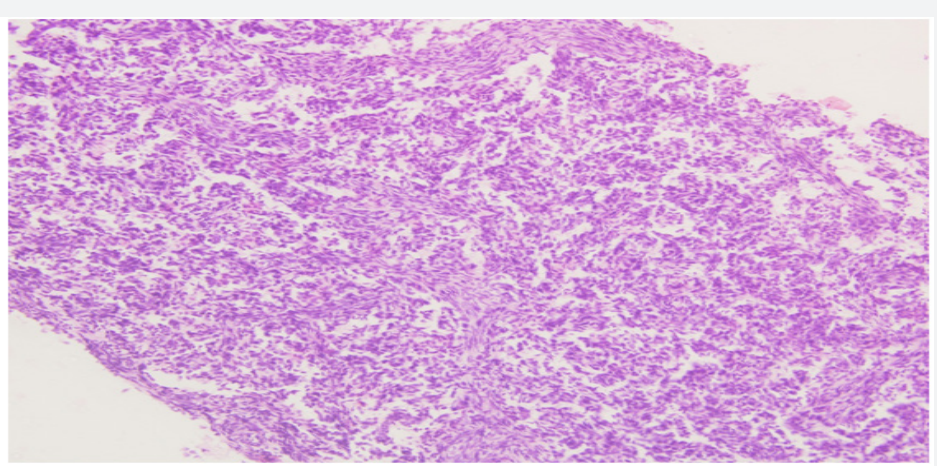

Figure 4: Histology picture of case 2.

LNs, ureter \& hilar vessels were free. IHC showed focal positivity with vimentin. Cytokeratin, Desmin and S100 were negative. CECT brain and bone scan of patient were done and suggested no metastasis. The patient was given chemotherapy as per COG Q9401 protocol for stage 1 CCSK consisting of Doxorubicin, Vincristine, Cyclophosphamide and Etoposide for 24 weeks. He received 10.8 Gy flank radiation also. Presently, the child is in regular follow up for last 1 year with no evidence of recurrence or metastasis.

\section{Case 2}

A 1.5-year-old female presented to us with accidently discovered progressively increasing asymptomatic mass in right flank since one month. There was no history of fever, loss of appetite, weight loss, hematuria, bone pain. Abdominal examination revealed a mass in the right lumbar region with right renal angle fullness. CECT showed 9x9x8cm well-defined heterogeneously enhancing lesion arising from mid and lower poles of the right kidney (Figure 3). No calcification was noted. Trucut biopsy showed tissue with infiltration by atypical cells with high nuclear: cytoplasmic $(\mathrm{N}: \mathrm{C})$ ratio, hyperchromatic irregular nuclei and scant cytoplasm (Figure 4). It was suggestive of round blue cell tumor, probably blastemal component of Wilms' tumor. Preoperative chemotherapy (AV regimen) was given over 4 weeks, but no response was noted. After 1 week, right nephroureterectomy with LN berry picking was done. Post- 
operative HPE was suggestive of CCSK. Capsule, perinephric fat, renal sinus, pelvis ureter, lymph nodes were free of tumor. The patient was given chemotherapy as for case 1. RT was not administered considering the age of the child. After 1 year of follow up, she is doing well with no evidence of local or distant recurrence.

\section{Discussion}

Non-Wilms' renal tumors account for less than $10 \%$ of primary renal neoplasm of childhood [7]. CCSK is an uncommon renal tumor in children but it comprise common unfavorable histology tumor in NWTS. It is named clear cell sarcoma for presence of abundant intracytoplasmic vesicles. CCSK has a propensity to permeate through the renal and perirenal vascular system [8]. The diagnosis of CCSK on trucut biopsy is difficult for the cytopathologist because it has many variant patterns like alterations of two kinds of cell types, cord, and septal cells.

Septal cells are spindle shaped whereas cord cells are polygonal in shape [3]. But it is possible to identify these cells on cytology if carefully looked for differences and this forms the key to diagnosis [9]. The cytopathologist should know the variable extent of these two cell types, because sampling of septal cells can lead to a false identification of a "biphasic" pattern and misdiagnosis as WT. Nine major histologic patterns of CCSK were identified in NWTS (classic, myxoid, sclerosing, cellular, epithelioid, palisading, spindle, storiform, and anaplastic); mostly tumors has blended multiple patterns [3].

In the classic pattern, the tumor cells appear monomorphic with cords or nests of 6-10 cells dispersed in arborizing fibrovascular septa. Nuclei are uniform in shape, with fine dusty chromatin without prominent nucleoli or coarse condensations [3]. IHC has been useful in differentiating CCSK from other childhood renal tumors. CCSK are cytokeratin and MIC 2 negative, thus ruling out Wilms' and PNET (Primitive Neuroendocrine Tumors) family. Tumor is non-reactive for S100, Synaptophysin, GFAP, LCA, and NSE. It shows immunoreactivity with Vimentin and non-specifically BCL2 positive $[3,10]$. The recurring translocations at $\mathrm{t}(10,17)$ has been also implicated in CCSK.[11]. The P53 gene product strikingly raised in anaplastic CCSK.

The current Children's Oncology Group protocol (AREN0321), follows the NWTS-5 regime for all CSSK patients (nephrectomy followed by radiotherapy and chemotherapy with cyclophosphamide, etoposide, vincristine, and doxorubicin for 24 weeks). Exceptions are those with stage IV disease who receive upfront therapy with irinotecan and vincristine; and those with stage I disease and negative lymph node sampling who do not undergo radiation therapy to the tumor bed [12]. The overall survival rate in CCSK quoted to be $69 \%$ but stage 1 tumor has good survival rate of $98 \%$.

The independent prognostic factors for survival in CCSK are treatment with doxorubicin, stage, age at diagnosis, and tumor necrosis [3]. The need for radiotherapy for stage 1 CCSK has been controversial. Radiotherapy may have late side effects on the musculoskeletal, hepatic, gastrointestinal, endocrine and cardiovascular function, second myeloid leukemia. Argani series highlighted the need of minimizing radiotherapy in view of high number of treatment related deaths in comparison to tumor related deaths [10]. The study from the SIOP Renal Tumor Study Group states the sequential reduction of treatment intensity for low-stage CCSK, focusing on the abolition of flank RT [13].

\section{Conclusion}

Though CCSK is totally distinct tumor from WT, preoperative trucut biopsy may fail to distinguish. Non-WT renal tumor like CSSK should be suspected if tumor does not respond to preoperative chemotherapy for WT and histology should be reviewed. Aggressive 24-week vincristine, doxorubicin, cyclophosphamide and etoposide regimen is required. Role of radiotherapy in stage 1 is falling out of order. Radiotherapy is mandatory in stages 2-4 [14]. We learnt from this experience of two patients that it is not only important to get pre-therapy biopsy of the pediatric renal tumors, but also to get them reported from experienced specialist pathologists so that the diagnosis of CCSK is not missed.

Secondly, it is emphasized that radiotherapy (RT) is probably not indicated in stage I CCSK and a universal consensus should be arrived at the fact.

\section{References}

1. Marsden HB, Lawler JB (1978) Bone metastasizing renal tumours of childhood. Br J Cancer 38(3): 437-441.

2. Mierau GW, Weeks DA, Beckwith JB (1989) Anaplastic Wilms tumor \& other clinically aggressive childhood renal neoplasms: Ultra structural and immunocytochemical features. Ultrastruct. Pathol 13(2-3): 225-248.

3. Argani P, Perlman EJ, Breslow NE, Browning NG, Green DM, et al. (2000) Clear cell sarcoma of kidney: A review of 351 cases from the National Wilms Tumor Study group Pathology Center. Am J Surg Pathol 24(1): 4-18.

4. Beckwith JB, Palmer NF (1978) Histopathology and prognosis of Wilms tumor: Results from the First national Wilms Tumor Study. Cancer 41(5): 1937-1948.

5. Kusumakumary P, Chellam VG, Rojymon J, Hariharan S, Krishnan NM (1997) Late recurrence of clear cell sarcoma of kidney. Med Pediatr Oncol 28(5): 355-357.

6. Kusumakumary P, Mathews A, James FV, Chellam VG, Hariharan S, et al (1999) Clear cell sarcoma kidney: clinical features and outcome. Pediatr Hematol Oncol 16(2): 169-174.

7. Broecker B (2000) Non-Wilms renal tumors in children. Urol Clin North Am 27(3): 463-469.

8. Murphy WM, Beckwith JB, Farrow GM (1993) Tumors of the kidney, bladder and related urinary structures. (Third Series, Fasicle 11) Washington DC: The Armed Forces Institute of Pathology 20(9): 67-81.

9. Iyer VK, Agarwala S, Verma K (2005) Fine needle aspiration cytology of clear cell sarcoma of the kidney: Study of eight cases. Diagn Cytopathol 33(2): 83-89.

10. Coran AG, Caldamone A, Adzick NS, Krummel TM, Laberge JM, et al. (2012) Pediatric Surgery $\left(7^{\text {th }}\right.$ edn), Elsevier Health Sciences, Wilms Tumor, Pennsylvania, USA pp. 437. 
11. Rakheja D, Weinberg AG, Tomlinson GE, Partridge K, Schneider NR (2004) Translocation $(10 ; 17)(q 22 ; p 13)$ : a recurring translocation in clear cell sarcoma of kidney. Cancer genetics and cytogenetics 154(2): 175-179.

12. Sinha S, Khurana N, Sarin YK (2014) Clear cell sarcoma of the kidney: report of two cases. APSP J Case Rep 5(3): 32.

13. Furtwängler R, Gooskens SL, van Tinteren H, de Kraker J, Schleiermacher G, et al. (2013) Clear cell sarcomas of the kidney registered on International Society of Pediatric Oncology (SIOP) 93-01 and SIOP 2001 protocols: a report of the SIOP Renal Tumour Study Group. Eur J Cancer 49(16): 3497-3506.

14. Spreafico F, Gandola L, Melchionda F (2014) Stage I clear cell sarcoma of the kidney: is it the time for a less intensive adjuvant treatment? Transl Pediatr 3(1): 1-3.

\section{Your next submission with Juniper Publishers will reach you the below assets}

- Quality Editorial service

- Swift Peer Review

- Reprints availability

- E-prints Service

- Manuscript Podcast for convenient understanding

- Global attainment for your research

- Manuscript accessibility in different formats ( Pdf, E-pub, Full Text, Audio)

- Unceasing customer service

Track the below URL for one-step submission https://juniperpublishers.com/online-submission.php 